\title{
The Argument Structures of Seven MUI Fatwas on the Pandemic Throughout 2020: How They Nurture the People Maslahah
}

\author{
$1^{\text {st }}$ Bambang Husni Nugroho ${ }^{1}, 2^{\text {nd }}$ Ahmad Mustaniruddin ${ }^{2}$ \\ \{bambanghusninugroho@uinjambi.ac.id ${ }^{1}$, ahmad_mustanirruddin@uinjambi.ac.id² $\}$ \\ UIN Sulthan Thaha Saifuddin Jambi ${ }^{1}$
}

\begin{abstract}
This paper analyzes seven MUI fatwas related to the pandemic that was produced throughout 2020 from the aspect of the argumentation structure used. This research is literature research with qualitative method and Usul Fiqh approach. The source of data in this study is literature which was analyzed using content analysis techniques. This paper shows the fact that in issuing a fatwa, although with a relatively narrow and close time span, MUI has tried hard to carry out its role to provide guidance and guidance to Indonesian Muslims in realizing religious and social life. From the structure of the arguments for the seven fatwas, it also seems to be an indication of the openness of the MUI and an indication of the close relationship between the MUI and the government.
\end{abstract}

Keywords: Argument Structure, Fatwas, MUI, Pandemic Fatwas

\section{Introduction}

Since Covid-19 was declared by the World Health Organization (WHO) as a pandemic in the world on March 9, 2020 [1]. MUI has issued at least seven fatwas regarding the pandemic throughout 2020. The fatwas are Fatwa Number 14 of 2020 concerning the Implementation of Worship in Situations of the Covid-19 Outbreak which was issued on March 16, 2020; Fatwa Number 17 of 2020 concerning Guidelines for Prayers for Health Workers who Wear Personal Protective Equipment (PPE) when Caring for and Handling Covid-19 Patients issued on March 26, 2020; Fatwa Number 18 of 2020 concerning Guidelines for the Management of the Corpses of Muslims Infected with Covid-19 issued on 27 March 2020; Fatwa Number 23 of 2020 concerning the Utilization of Zakat, Infaq, and Sadaqah Assets for Combating the Covid-19 Outbreak and its Impacts, issued on April 16, 2020; Fatwa Number 28 of 2020 concerning Guidelines for Takbir and Eid Prayers During the Covid-19 Pandemic published on May 13, 2020; Fatwa Number 31 of 2020 concerning the Implementation of Friday Prayers and Congregations to Prevent the Transmission of the Covid-19 Outbreak, which was issued on June 4, 2020; Fatwa Number 36 of 2020 concerning Eid al-Adha Prayers and the Slaughter of Sacrificial Animals During the Covid-19 Outbreak, which was issued on July 6, 2020.

As can be seen, all of these fatwas were issued in a relatively close period of time. This phenomenon clearly shows the productivity of MUI in giving fatwas in responding to the pandemic. 
So far, various writings about the pandemic and the reaction of Muslims to it have been produced by several scholars. Ahmad Mukafi Niam, Oman Fathurahman, and Masdar Hilmy and Khoirun Niam have produced writings that portray the pandemic from various aspects. Ahmad Mukafi Niam indicated that in delivering his da'wah, the theology adopted by the dai (preacher) is a factor that determines what he conveys in relation to the pandemic. A preacher who holds a fatalist theology has the potential to convey the theology to the object of his da'wah and even invites them to ignore health protocols so that they have the potential to be exposed and transmit it to others [2]. Responding to this, it seems, Oman Fathurahman is trying to shed some light by explaining the refutation of the fatalist narrative as above while alluding to the book Badhl al-Ma $>$ ' $\mathrm{u}>\mathrm{n}$ fi Fadl al-T $\{\mathrm{a}>$ ' $\mathrm{u}>\mathrm{n}$ by al-Asqalani $>\mathrm{y}$. who wrote the book after losing three of his daughters in a plague year. The work which was later proofread by a philologist named Ah \} mad Is $\} a>m$ 'Abd al-Qadi>r al-Ka>tib was declared by Fathurahman as a work that was quite complete in exploring the plague of the year both medically and metaphysically [3].

Masdar Hilmy and Khoirun Niam provide a more comprehensive explanation of the various reactions of contemporary Indonesian Muslims in responding to the pandemic. Using data obtained from social media and other media such as newspapers, both concluded that in responding to the Covid-19 pandemic, contemporary Indonesian Muslims are divided into two groups: Those who are rational and use inductive reasoning, and; those who are textual and use deductive reasoning.[4]

On the other hand, one can find a number of studies on MUI. Among the pioneering research on this is the research of $\mathrm{M}$. Atho Mudzhar. In his research, Mudzhar determines which MUI fatwas are neutral or influenced by the government and categorizes MUI fatwas into five categories according to their broadcast and public acceptance. Mudzhar concluded that of the 22 MUI fatwas he tested, there were 11 that were considered neutral, there were eight that were considered quite neutral but had influence from the government and there were three fatwas that were considered quite neutral and lacked/no influence from the government. Meanwhile, the MUI fatwa is based on the broadcast and public acceptance of it. Mudzhar divides it into: Fatwas which are widely circulated but do not cause conflict; A fatwa that is not widespread and does not cause conflict; The fatwa, which was widely circulated, caused conflict and the government was neutral; The fatwa, which was widely circulated, caused little controversy, the government welcomed it, as well as; The fatwa was widely circulated, caused a lot of opposition, the government did not like it.[5] This pioneering research was followed by a number of scholars such as M. B. Hooker M. B. Hooker, Indonesian Islam: Social Change Through Contemporary Fata>wa> (New South Wales: Allen \& Unwin, 2003)., Nico J. G. KapteinNico J.G. Kaptein, "The Voice of the 'Ulamă': Fatwas and Religious Authority in Indonesia," Archives de Sciences Sociales Des Religions 125, no. 1 (2004): 115-30, https://doi.org/10.4000/ assr.1038., Nadirsyah and Moch [8]. Nur Ichwan[9]. Research on the Muhammadiyah Tarjih Council has at least been carried out by Syamsul Anwar[10], while research on Lajnah Bahtsul Masail Nahdlatul Ulama, for example, has been carried out by Rifyal Ka'bah[11], Ahmad Zahro[12], Michael Laffan[13], and Achmad Kemal Riza[14], [15].

The number of academics who study MUI, especially the fatwas produced by it, shows its existence in the midst of the government and society. The seriousness of the MUI in responding to the covid-19 pandemic is evidenced by the issuance of seven fatwas regarding COVID-19 in a relatively close time span. The existence of the MUI is certainly not obtained easily, it takes struggle and effort in compiling a good and accountable argument structure in producing fatwas during this covid 19 in order to maintain the benefit in the midst of society. For this reason, this paper will look at the structure of the arguments used by MUI in producing the seven fatwas during the COVID-19 pandemic above. 


\section{Methodology}

The method in question is the steps or procedures in conducting research. The procedures include the type of research, research subjects, and data sources as well as data analysis techniques. Each procedure is explained as follows: based on the object, this research is literature research with qualitative methods and Usul Fiqh approach.

To obtain information related to the research, the researchers dug up data from library sources, namely seven MUI fatwas on the pandemic throughout 2020, starting with Fatwa Number 14 of 2020 concerning the Implementation of Worship in the Situation of the Covid19 Outbreak, which was published on March 16, 2020 on Fatwa Number 36 of 2020. 2020 concerning Eid al-Adha Prayers and Slaughtering of Sacrificial Animals During the Covid-19 Outbreak, which was published on July 6, 2020.

In analyzing all of the fatwas above, using content analysis techniques, the researcher then describes in detail the results of the analysis that has been carried out on the literature of seven MUI fatwas throughout 2020.

\section{Result and Discussion}

\subsection{Seven MUI fatwas throughout 2020 regarding the covid-19 pandemic}

The first fatwa issued by MUI as a reaction to the Covid-19 pandemic was Fatwa Number 14 of 2020 concerning the Implementation of Worship in Situations of the Covid-19 Outbreak, which was issued on March 16, 2020. This fatwa was apparently issued by including quotes from eight verses of the Qur'an. , 10 pieces of hadith, seven rules of fiqh, as well as quotes from two books, namely al-Majmu>' Sharh \} al-Muhadhdhab by al-Nawawi>y (D. $676 \mathrm{H})$ and Muqaddimah al-H\{ad\}rami $>$ yah by $\mathrm{Ba}>$ fad $\}$ al (D. $918 \mathrm{H}$ ). Ba>fad $\}$ al's Muqaddimah al$\mathrm{H}\{\mathrm{ad}\} \mathrm{rami}>\mathrm{yah}(\mathrm{D} .918 \mathrm{H})$ is classified by Bruinessen as one of four text families used by Sha>fi'i $>$ yah scholars in Indonesia. There are three manuscripts which Bruinessen concludes as derivatives of $\mathrm{Ba}>\mathrm{fad}\}$ al's Muqaddimah al-H $\{\mathrm{ad}\} \mathrm{rami}>\mathrm{yah}$, namely Minha $>\mathrm{j}$ al-Qawi $>\mathrm{m}$ by alHaitami>y (D. 973 H), Sharh \} 'ala Ba>fad \}al by Mah\}fu>z\} al-Tarmasi>y (D. 1338 H), and Bushra al-Kari>m by Sa'i>d ibn Ba>'ashin (D. $1270 \mathrm{H}$ ). The other three text families are the manuscript family which is sourced from the al-Muh \}arrar manuscript by al-Ra>fi'i $>$ (W. 623 $\mathrm{H})$, the text family which is sourced from the Taqri>b manuscript by Abu> Shuja>' (D. $593 \mathrm{H}$ ), and a family of texts derived from the Qurrat al-'Ain manuscript by al-Malibari> (d. around 975 H) [16]. It should be noted here that this fatwa can be considered very responsive because it was issued only seven days after Covid-19 was declared by the World Health Organization (WHO) as a pandemic in the world on March 9, 2020. The number of arguments presented also show the seriousness of the MUI in the formulation of this fatwa.

The second fatwa was issued 10 days later in the form of Fatwa Number 17 of 2020 concerning Guidelines for Prayers for Health Workers who Wear Personal Protective Equipment (PPE) when Caring for and Handling Covid-19 Patients issued on March 26, 2020. This fatwa includes quotes from seven verses Al-Qur'an, 10 hadiths, and six fiqh rules. This second fatwa includes quotes from seven books, namely Fath $\}$ al-Ba>ri>y by al-'Asqalani $>y$ (D. $852 \mathrm{H}$ ), al-Radd al-Mukhta $>\mathrm{r}$ 'ala al-Durr al-Mukhta $>$ r by Ibn 'A<bidi>n (D. $1252 \mathrm{H}), \mathrm{Al}$ Umm by al-Sha>fi'i>y (D. 204 H), Sharh \} al-Nawawi>y 'ala Muslim by al-Nawawi> y (D. 676 H), Al-Majmu>' Sharh\} al-Muhadhdhab by al-Nawawi>y (D. 676 H), Kifa>yat al-Akhya>r by 
al-H\{is $\}$ ni $>$ y ( D. $829 \mathrm{H}$ ), and Al-Mughni>y by Ibn Quda>mah (D. $620 \mathrm{H}$ ). There are four interesting things that should be noted from this second fatwa. First, although this fatwa is accompanied by a large number of quotes from the book of Sha>fi'i>yah, it turns out that this fatwa also quotes from Al-Umm by al-Sha>fi'i>y (D. $204 \mathrm{H}$ ), a practice that is quite rare in the recent development of fatwas. A similar phenomenon also occurs in individual ulama fatwasBambang Husni Nugroho, "Metode Ijtihad Guru Muhammad 'Ali Ibn 'Abd Al-Wahhab Al-Tunkali Dalam Kitab Al-Fatawa Al-Tunkaliyah,” 2019, 237, https://repository.uinjkt.ac.id/dspace/handle/ 123456789/50350., confirms the findings by Mudzhar in his study of MUI and Zahro in his previous study of LBM-NU.[12] Second, although quotations from the Sha>fi'i> yah school seem to dominate, MUI also does not hesitate to quote from the book of Al-Mughni>y by Ibn Quda>mah (D. $620 \mathrm{H}$ ) which holds the view of $\mathrm{H}\{$ ana $>$ bilah and Radd al-Mukhta $>$ r 'ala al-Durr al-Mukhta $>$ r by Ibn 'A<bidi $>n$ (D. $1252 \mathrm{H}$ ) who holds the view of $\mathrm{H}$ \{ anafi>yah fiqh. This fact at least shows the openness of MUI to accept views other than Sha>fi'i>yah, even though in general the Sha>fi'i>yah school is a school that is generally adopted by Indonesians. Third, the MUI's willingness to use the explanations of Budi Sampurno (FKUI Professor) and Wiku Adisasmito (Chairman of the Covid-19 Task Force Expert Team) as one of the considerations for his fatwa also shows MUI's willingness to become the government's partner in the successful handling of the Covid-19 pandemic in Indonesia. Fourth, making Fatwa Number 14 of 2020 Concerning the Implementation of Worship in Situations of the Covid-19 Outbreak which was published on March 16, 2020, as one of the arguments, of course, shows the consistency of MUI in the legal view of its fatwa. These four facts have to be an important note when discussing this fatwa.

The day after the second fatwa as described above, Fatwa Number 18 of 2020 concerning Guidelines for the Management of the Corpses of Muslims Infected with Covid-19 was issued on 27 March 2020. Fewer than the two previous fatwas, this third fatwa only quoted four verses of the Qur'an. and, although he also quoted a number of hadiths in quite a lot, namely a number of nine hadiths. This fatwa is also identified as quoting six fiqh rules and quotes from six books, namely Sharh \} al-Nawawi>y 'ala Muslim by al-Nawawi>y (D. 676 H), Al-Majmu>' Sharh\} alMuhadhdhab by al-Nawawi> -Nawawi>y (D. $676 \mathrm{H}$ ), Sullam al-Taufi>q by 'Abd Alla $>\mathrm{h}$ ibn $\mathrm{H}$ \{usain Ba'alawi>y (D. 1272 H), al-Fiqh 'ala al-Madha>hib al -Arba'ah by al-Jazi>ri>y (D. $1359 \mathrm{H}$ ), Niha>yat al-Zain by Nawawi>y al-Bantani>y (D. 1314 H), and Mughn al-Muh\}ta>j the work of al-Sharbaini>y (D. $977 \mathrm{H}$ ). It is interesting to say here, the explanations of Budi Sampurno (Professor of FKUI) and Wiku Adisasmito (Head of the Covid-19 Task Force Expert Team) are again became one of the considerations for this fatwa. The two previous fatwas are also arguments that strengthen this fatwa. One thing that is most interesting is of course the MUI's willingness to refer to the MUI Fatwa of DKI Jakarta Province Number 01 of 2020 concerning Laws and Guidelines for Handling Covid-19 Infected Corpses as an argument for this fatwa. It seems that the urgency of issuing a fatwa regarding guidelines for the management of corpses infected with Covid-19 has succeeded in making MUI refer to the regional level MUI fatwa and include it as one of its fatwa arguments, an unusual practice.

The MUI fatwa regarding the fourth pandemic is Fatwa Number 23 of 2020 concerning the Utilization of Zakat, Infaq, and Sadaqah Assets for Combating the Covid-19 Outbreak and its Impacts which was published on April 16, 2020. This fatwa argues with six verses of the Qur'an, six hadiths, three fiqh rules, three fiqh books, namely Al-Majmu>' Sharh\}\} al-Muhadhdhab by al-Nawawi>y (D. 676 H), Niha>yat al-Muh\}ta>j by al-Ramli>y (D. 1004 H), and Al-Mughni>y by Ibn Quda>mah (D. $620 \mathrm{H})$. This fatwa also cites the views of two commentaries, namely Tafsi>r al-Mara>ghi>y by al-Mara>ghi>y (D. 1952 AD) and Mafa>tih $\}$ al-Ghaib by al-Ra>zi>y (D. 1210 AD). Two things should be noted from this fatwa: First, the willingness of MUI to 
quote the views of al-Razi>y, which some people have accused of being the Mu'tazilah theological school [18], also again described the openness of MUI. Second, this fatwa also refers to the existing fatwas. MUI's steps refer to the two previous fatwas (MUI Fatwa Number 14 of 2020 concerning the Implementation of Worship in Situations of a Covid-19 Outbreak and MUI Fatwa Number 17 of 2020 concerning Guidelines for Prayers for Health Workers Who Use Personal Protective Equipment (PPE) When Caring and Handling Covid-19 patients). MUI's willingness to refer to the DKI Jakarta Province MUI Fatwa Number 04 of 2020 concerning the Law on the Utilization of Zakat for the Procurement of Disinfectants, Hand Sanitizers, Masks, and Personal Protective Equipment (PPE) in the Covid-19 Outbreak Situation, as well as its willingness to refer to its fatwas far published earlier (MUI 1982 Fatwa Concerning the Intensification of Zakat Implementation, 1982 MUI Fatwa concerning Tasharruf Zakat Funds for Productive Activities and Public Benefit, 1996 MUI Fatwa Regarding Scholarship Zakat Giving, 2015 MUI Fatwa concerning Distribution of Zakat Assets in the form of Managed Assets, and the 2015 MUI Fatwa concerning the Utilization of Assets of Zakat, Infaq, S \{adaqah, Waqf for the Development of Clean Water and Sanitation Facilities for the Community) seems to emphasize its consistency in giving fatwas and at the same time showing recognition that the previous fatwas have had the right views and legal arguments even if collided with current needs.

The fifth fatwa is Fatwa Number 28 of 2020 concerning Guidelines for Kaifiat Takbir and Eid Prayers During the Covid-19 Pandemic which was published on May 13, 2020. As is known, Eid in 2020 falls on May 24, 2021 [19]. The issuance of this fatwa in a pandemic atmosphere certainly answers people's questions about the merits of Eid al-Fitr celebrations during the pandemic. This fatwa argues with seven verses of the Qur'an, 11 hadiths, five rules of fiqh, and quotes from nine books, namely Al-Umm by al-Sha>fi'i>y (D. 204 H), Al-Ha>wi al-Kabi>r by al-Ma>wardi>y (D. 450 H), Al-Majmu>' Sharh\} al-Muhadhdhab by al-Nawawi>y (D. 676 H), Raud $\}$ at al-T $\{$ a $>$ libi>n by al-Nawawi>y (D. 676 H), Al-Iqna>' by al-Ma>wardi >y (D. 450 H), Mukhtas \}ar al-Muzani>y by al- Muzani>y, Niha $>$ yat al-Mat $\}$ lab by Ima $>m$ al-H $\{$ aramain (D. $478 \mathrm{H})$, Bada>'i' al-S $\{$ ana $>$ 'i $>$ y by al-Kasa>ni>y (D. $587 \mathrm{H})$, and Tuh \}fat al-Fuqaha ' by alSamarqandi>y (D. 539 H). The previous two fatwas, namely MUI Fatwa Number 14 of 2020 concerning the Implementation of Worship in Situations of a Covid-19 Outbreak and MUI Fatwa Number 17 of 2020 concerning Guidelines for Prayers for Health Workers Who Use Personal Protective Equipment (PPE) When Caring for and Handling Covid-19 Patients 19 is again used as an argument for this fatwa. In addition to books with the Sha>fi'i>yah school of thought, it turns out that MUI has again used two books written by $\mathrm{H}\{$ anafi $>$ yah scholars, namely Bada>'i' al-S $\{$ ana>'i>y by al-Kasa>ni>y (D. $587 \mathrm{H})$ and Tuh $\}$ fat al-Fuqaha>' by alSamarqandi>y (D. $539 \mathrm{H})$. One thing that is interesting is that for the first time Indonesian Muslims were introduced to perform Eid prayer at home, different from what has been done so far. This is a progressive breakthrough that has never been recorded before in the history of MUI [20].

The sixth fatwa is Fatwa Number 31 of 2020 concerning the Implementation of Friday Prayers and Congregations to Prevent the Transmission of the Covid-19 Outbreak which was issued on June 4, 2020. This fatwa argues with eight verses of the Qur'an, nine hadiths, eight rules of fiqh, and nine quotes from fiqh books, namely Niha>yat al-Muh\}ta $>\mathrm{j}$ by al-Ramli $>\mathrm{y}$, Dali $>1$ al-Fa $>$ lih $\} \mathrm{i}>\mathrm{n}$ by Ibn 'Alla $>\mathrm{n}$ al-S $\{$ iddi $>$ qi $>$ y, Bada $>$ 'i' al-S $\{$ ana $>$ 'i $>$ y fi $>$ y Tarti $>b$ alShara $>$ 'i $>$ y by al-Kasa $>$ ni $>$ y (D. 587 H), al-Radd al -Mukhta $>$ r 'ala al-Durr al-Mukhta $>$ r by Ibn 'A<bidi>n (D. 1252 H), Al-Majmu' Sharh\} al-Muhadhdhab by al-Nawawi>y (D. 676 H), AlIns $\} a>f$ fi $>$ y Ma'rifat al-Ra $>$ jih $\}$ min al-Khila $>$ f by al-Mura $>$ wadi $>y$, 'Aun al-Ma'bu $>d$ by Shams al-H\{aqq 'Abadi>y, Al-Ha>wi al-Kabi>r by al-Ma>wardi>y, and Kashsha>f al-Qanna>' 
by al-Bahu>t\}i $>y$ (D. $1051 \mathrm{H})$. In addition, this fatwa also argues with the MUI Fatwa Number 5 of 2000 concerning the Implementation of Two Waves of Friday Prayers, the MUI Fatwa Number 14 of 2020 concerning the Implementation of Worship in Situations of the Covid-19 Outbreak, and the DKI Jakarta Province MUI Fatwa Number 5 of 2020 concerning Laws. and Guide to Friday Prayers More Than Once During the Covid-19 Pandemic. Again, this fatwa cites books by scholars with the $\mathrm{H}$ \{ anafi> yah and $\mathrm{H}$ \{ ana>bilah views in addition to the works of scholars with the Sha>fi'i>yah view. These books are Bada>'i' al-S $\{$ ana $>$ 'i $>y$ fi $>y$ Tarti $>b$ alShara $>$ 'i $>$ y by al-Kasa>ni>y (D. $587 \mathrm{H}$ ) and Radd al-Mukhta $>$ r 'ala al-Durr al-Mukhta $>$ r by Ibn 'A<bidi>n (D. $1252 \mathrm{H}$ ) from the $\mathrm{H}\{$ anafi $>$ yah and Kashsha $>$ f al-Qanna $>$ ' by al- Bahu>t $\} \mathrm{i}>\mathrm{y}$ (D. $1051 \mathrm{H})$ from the scholars of $\mathrm{H}\{$ ana $>$ bilah.

The last fatwa discussed in this paper is Fatwa Number 36 of 2020 concerning Eid al-Adha Prayers and the Slaughter of Sacrificial Animals During the Covid-19 Outbreak which was published on July 6, 2020[21]. This fatwa was issued shortly after the decision to cancel the delivery of Indonesian Hajj pilgrims in 2020 by the Minister of Religion through Minister of Religion Decree Number 494 of 2020 dated June 2, 2020.[22] This decision seems to put an additional burden on the MUI because it is clear to Indonesian Muslims that 2020 Eid will only be celebrated with Eid prayers and the slaughter of sacrificial animals. That spirit seems to be one of the spirits of issuing fatwas in addition to a sense of responsibility to maintain the safety of the people in carrying out their worship. Nine verses of the Qur'an, 23 hadiths, five fiqh rules, and quotes from six fiqh books were chosen by MUI as arguments for this fatwa. So far, this is the fatwa with the most hadith quotes. Quotes from Al-Ha>wi al-Kabi>r by al-Ma>wardi>y (D. $450 \mathrm{H}$ ), Al-Mughni>y by Ibn Qudamah (D. 620 H), Al-Mabsu>t $\}$ by al -Sarkhasi>y (D. 490 H), Al-Hida>yah fi>y Sharh\} Bida>yat al-Mubtadi>y by al-Marghina>ni>y (D. 593 H), Al-Bah\}r Ra>'iq Sharh\} Kanz Daqa>'iq by Ibn Nujaim (D. 970 H), and Al-Wasi>t\} fi al-Madhhab by $\mathrm{Abu}>\mathrm{H}\{\mathrm{a}>\mathrm{mid}$ al-Ghaza>li>y (D. $505 \mathrm{H}$ ) along with MUI Fatwa Number 12 of 2009 concerning Standards for Certification of Halal Slaughter, MUI Fatwa Number 37 of 2019 concerning Preservation and Distribution of Sacrificial Meat in Processed Form, MUI Fatwa Number 14 of 2020 concerning Implementation of Worship in Situations of a Covid-19 Outbreak, MUI Fatwa Number 28 of 2020 concerning Guidelines for Kaifiat Takbir and Eid Prayer during the Covid-19 Pandemic, MUI Fatwa Number 31 of 2020 concerning the Implementation of Friday and Congregational Prayers to Prevent the Transmission of the Covid19 Outbreak, Fatwa of the MUI of DKI Jakarta Province Number 6 of 2020 concerning The Law of Sacrifice With Money During the Covid-19 Pandemic be an argument for this fatwa as well. Again, a quote from the views of non-Sha>fi'i>yah scholars is seen here. Al-Mughni>y by Ibn Qudamah (D. $620 \mathrm{H}$ ) again represents the views of the scholars of $\mathrm{H}\{$ ana $>$ bilah, while AlMabsu>t $\}$ by al-Sarkhasi >y (D. 490 H), Al-Hida>yah fi >>y Sharh \} Bida>yat al-Mubtadi>y by al-Marghina>ni>y (D. 593 H) and Al-Bah\}r Ra>'iq Sharh\} Kanz Daqa>'iq by Ibn Nujaim (D. $970 \mathrm{H}$ ) represents the fiqh views of the $\mathrm{H}$ \{anafi>yah scholars. The reliance of arguments on previous fatwas again demonstrates the consistency of MUI in its views and arguments for its fatwas.

\subsection{Classification of arguments: from main to supporting}

From the facts above, several things can be seen. These seven fatwas are actually equipped with many naqli arguments. The seven fatwas can be said to quote many verses of the Qur'an as legal arguments. The fatwa that quotes the most verses from the Qur'an is Fatwa Number 36 of 2020 concerning Eid al-Adha Prayers and the Slaughter of Sacrificial Animals During the Covid-19 Outbreak with 10 verses in nine places. The fatwa that at least cites verses from the 
Qur'an is Fatwa Number 18 of 2020 concerning Guidelines for the Management of Muslim Bodies Infected with Covid-19 with four verses. The seven fatwas each quote a total of seven verses of the Qur'an on average. The verse quoted in each fatwa is the Qur'an surah Al-Baqarah verse 185,[23]\ namely:

... Allah desireth for you ease; He desireth not hardship for you ...

$$
\text { ...يُرِيدُ اللَهُ بِكُمُ الْيُسْرَ وَلاَ بَرِيدُ بِكُمُ الْعُسْرَ .... }
$$

The second most quoted verse (in the five fatwas) is the Qur'an surah al-Tagha $>b u>n$ verse 16 [23], namely:

So keep your duty to Allah as best ye can ...

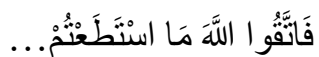

The seven fatwas can be said to quote many hadiths as legal arguments as well. The fatwa citing the most hadiths is Fatwa Number 36 of 2020 concerning Eid al-Adha Prayers and the Slaughter of Sacrificial Animals During the Covid-19 Outbreak with 23 hadiths. The fatwa that at least cites hadith is Fatwa Number 23 of 2020 concerning the Utilization of Zakat, Infaq, and Sadaqah Assets for Combating the Covid-19 Outbreak and its Impact with six hadiths. The seven fatwas each quote a total of 11 hadiths on average. The most cited hadith (in three fatwas) is the hadith narrated by Muslims [24].

\section{Don't mix the sick with the healthy}

$$
\text { لا يورِدِ مُمرِض على مُصِح }
$$

In addition, the seven fatwas can be said to quote many fiqh rules as legal arguments. The most fatwa citing fiqh rules is Fatwa Number 31 of 2020 concerning the Implementation of Friday and Congregational Prayers to Prevent the Transmission of the Covid-19 Outbreak with eight fiqh rules. The fatwa that at least cites fiqh rules is Fatwa Number 23 of 2020 concerning the Utilization of Zakat, Infaq, and Shadaqah Assets for Overcoming the Covid-19 Outbreak and its Impact with three fiqh rules. The seven fatwas each quote a number of six fiqh rules on average. The two most cited fiqh rules (in the six fatwas) are:

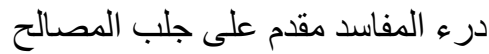

Rejecting damage takes precedence over seeking benefit Abu Ishak Ibrahim bin Musa bin Muhammad Allakhami al-Gharnathi Syathibi, Al-Muwafaqat (Dar Ibnu Affan, 1997), vol. VI, 446.

Difficulty leads to

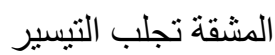

The second most quoted figh rule (in five fatwas) is:

$$
\text { تصرف الإماحِ على الر عية منوط بالمصلحة }
$$

The policy of the leader (holder of authority) towards the people must follow the benefit alSuyuthi, vol. I, 121. 
In the seven fatwas regarding this pandemic, MUI can be said to be very responsive in answering people's problems. A total of seven fatwas were successfully produced during the March-July 2020 period. In these seven fatwas, MUI can be said to use a lot of arguments. A total of seven verses of the Qur'an, 11 hadith, and six fiqh rules are used on average in each fatwa. It can be seen that although it was produced in a relatively narrow and close time span, MUI has tried hard to carry out its role to provide guidance and guidance to Indonesian Muslims in realizing a religious and social life that is blessed by Allah Subhanahu wa Taala, as the first goal of its establishment.

In addition to the arguments of the Qur'anic verses, hadith, and fiqh rules, the seven fatwas also rely on quotes taken from fiqh books. The views of the Sha>fi'i>yah scholars seem to dominate in the use of arguments. The views of al-Nawawi>y, al-Ma>wardi>y, and the Sha $>$ fi' $i>$ yah scholars are often used as arguments in these seven fatwas. The view of alNawawi>y in al-Majmu>' Sharh\} al-Muhadhdhab looks more prioritized because it is quoted in the seven fatwas, in some fatwas quoted more than once, surpassing the view of al-Sha>fi'i>y in al-Umm which only quoted twice in seven fatwas. Al-Nawawi>y's views are also quoted from his other works, Raudat al-T\{a>libi>n and Sharh $\} \mathrm{S}\{\mathrm{ah}\{\mathrm{i}>\mathrm{h}\{$ Muslim. The view of al$\mathrm{Ma}>$ wardi $>\mathrm{y}$ in al-Ha $>$ wi al-Kabi $>\mathrm{r}$ and al-Iqna $>$ is the second most widely quoted view of the Sha $>$ fi' $i>y a h$ scholars. It is interesting to mention, some quotes from the views of $\mathrm{H}\{$ anafi $>$ yah and $\mathrm{H}\{$ ana $>$ blalah scholars can also be found here and there. al-Sarkhasi $>y$ 's view in alMabsu>t $\}$, al-Kasa>ni $>y$ 's view in Bada>'i' al-S $\{$ ana $>$ ' $>y$ fi $>y$ Tarti $>b$ al-Shara $>i>y$, the views of Ibn Nujaim in al-Bah\}r Ra>'iq Sharh\} Kanz Daqa>'iq, up to the views of al-Samarqandi>y in Tuh\}fat al-Fuqaha> ' can be found quoted from the work of scholars $\mathrm{H}$ \{ anafi> well. Likewise, the view of Ibn Qudamah in al-Mughni>y, the view of al-Mura>wadi $>y$ in al-Ins $\} a>f$ fi $>y$ Ma'rifat al-Ra>jih $\}$ min al-Khila>f, until the view of al- Bahu>t $\}$ i $>y$ in Kashsha $>f$ al-Qanna $>$ can also be found quoted from the work of scholars $\mathrm{H}\{$ ana>blalah. This phenomenon is a trend that has been reported for quite some time. However, in these seven fatwas, it appears that a significant shift has occurred in the priority of using fiqh references by the MUI. The views of al-Dimyat $\} \mathrm{i}>\mathrm{y}$ and al-Haitami $>\mathrm{y}$ which were previously reported to be quite dominant, appear to have not been used at all in these seven fatwas.

In addition, MUI also relies on the views of medical experts and the government's views by accommodating the views of Budi Sampurno (Professor of FKUI) and Wiku Adisasmito (Chairman of the Covid-19 Task Force Expert Team) on two fatwas, namely Fatwa Number 17 of 2020 concerning Guidelines for Prayers for Health Workers Who Use Personal Protective Equipment (PPE) When Caring for and Handling Covid-19 Patients and Fatwa Number 18 of 2020 concerning Guidelines for the Management of Muslim Bodies Infected with Covid-19. MUI also seems consistent with its previous fatwas and takes them as a consideration. The MUI also seems not to hesitate to quote the Jakarta Provincial MUI fatwa on a similar issue which seems to have been responded to by the DKI Jakarta Provincial MUI by issuing a fatwa.

\section{Conclusion}

The seriousness of the MUI in formulating fatwas, especially the seven fatwas that address the COVID-19 pandemic during 2020, can be seen from the structure of the arguments it uses. Various references ranging from the Qur'an, Hadith, to expert opinions also complement MUI's efforts to account for these fatwas as evidence of its existence in maintaining the benefit of the community. The structure of the arguments for the seven fatwas during the COVID-19 period 
in 2020 can also be considered as an indication of the openness of the MUI and an indication of a fairly intimate relationship between the MUI and the government, as the fulfillment of the second and third objectives of its establishment, namely providing advice and fatwas regarding religious and social issues to the public, government and society, increasing activities for the realization of ukhwah Islamiyah and inter-religious harmony in strengthening national unity and integrity; be a liaison between the ulama and the umaro (government) and a reciprocal interpreter between the people and the government in order to succeed in national development.

\section{References}

[1] "Tanya Jawab | Covid19.go.id.” .

[2] A. M. Niam, "Antara Corona, Ulama, dan Sains." .

[3] "Corona dan Narasi Agama Kementrian Agama RI." .

[4] M. Hilmy dan K. Niam, "Winning the battle of authorities: The muslim disputes over the covid19 pandemic plague in contemporary Indonesia," Qudus Int. J. Islam. Stud., vol. 8, no. 2, 2021, doi: 10.21043/qijis.v8i2.7670.

[5] M. A. Mudzhar, "'Fatwa's' of the Council of Indonesian Ulama: A study of Islamic legal thought in Indonesia, 1975-1988," 1990.

[6] M. B. Hooker, Indonesian Islam: Social Change Through Contemporary Fata>wa>. New South Wales: Allen \& Unwin, 2003.

[7] N. J. G. Kaptein, "The voice of the 'Ulamă': Fatwas and religious authority in Indonesia," Arch. Sci. Soc. Relig., vol. 125 , no. 1, 2004, doi: 10.4000/assr.1038.

[8] N. Hosen, "Religion and the Indonesian Constitution: A recent debate," J. Southeast Asian Stud., vol. 36, no. 3, 2005, doi: 10.1017/S0022463405000238.

[9] M. N. Ichwan, "Ulama, State And Politics: Majelis Ulama Indonesia After Suharto.," Islam. Law Soc., vol. 12, no. 1, 2011.

[10] S. Anwar, "Fatwā, purification and dynamization: A study of tarjīh in muhammadiyah," Islam. Law Soc., vol. 12, no. 1, hal. 27-44, 2005, doi: 10.1163/1568519053123894.

[11] R. Ka'bah, "Keputusan Lajnah Tarjih Muhammadiyah dan Bahtsul Masail Nahdhatul Ulama sebagai Keputusan Ijtihad Jama'i di Indonesia," Universitas Indonesia, 1998.

[12] A. ZAHRO;, Tradisi intelektual NU: lajnah bahtsul masail 1926-1999/ Ahmad Zahro. Yogyakarta: LKiS, 2004.

[13] M. Laffan, "The Fatwā Debated? Shūrā in one Indonesian Context," Islam. Law Soc., vol. 12, no. 1, hal. 93-122, Jan 2005, doi: 10.1163/1568519053123920.

[14] A. K. Riza, "CONTEMPORARY FATAWA OF NAHDLATUL ULAMA: Between Observing the Madhhab and Adapting the Context," J. Indones. Islam, vol. 5, no. 1, hal. 35-65, Jun 2011, doi: 10.15642/JIIS.2011.5.1.35-65.

[15] K. Y. Soon, “Antara Tradisi dan Konflik: Kepolitikan Nahdlatul Ulama,” UI Press, 2008, hal. 256-257.

[16] M. Bruinessen, "Kitab kuning; Books in Arabic script used in the Pesantren milieu; Comments on a new collection in the KITLV Library," Bijdr. tot taal-, land-en Volkenkd. / J. Humanit. Soc. Sci. Southeast Asia, vol. 146, no. 2, 1990, doi: 10.1163/22134379-90003218.

[17] B. H. Nugroho, "Metode Ijtihad Guru Muhammad 'Ali ibn 'Abd Al-Wahhab Al-Tunkali dalam Kitab Al-Fatawa Al-Tunkaliyah," 2019.

[18] H. C. Erlwein, "Fakhr al-Dīn al-Rāzī on the Question 'Why Worship God?," https://doi.org/10.3366/jqs.2019.0381, vol. 21, no. 2, hal. 39-67, Jun 2019, doi: 10.3366/JQS.2019.0381.

[19] "Hari Raya Idul Fitri Sabtu atau Minggu? Ini Jadwal Lebaran 2020 Versi Pemerintah dan Muhammadiyah - Halaman all - Tribunnewswiki.com.”.

[20] "Imbas Covid-19, Masjid Raya Jakarta Islamic Center Tiadakan Shalat Tarawih dan Shalat Idul 
Fitri.".

[21] "Kapan Idul Adha 2020? Ini Informasinya." .

[22] "Kementerian Agama resmi membatalkan keberangkatan jemaah haji tahun 2020."

[23] Kementerian Agama RI, Al-Qur'an Tajwid dan Terjemahnya. Bandung: Sygma Examedia Arkanleema, 2021.

[24] Muslim bin Hajjaj bin Muslim Al-Qusyairi Al-Naisabury, Shahih Muslim. Beirut: Dar al-Fikri, 2003.

[25] A. I. I. bin M. bin M. A. al-G. Syathibi, Al-Muwafaqat. Dar Ibnu Affan, 1997.

[26] A. al-R. bin A. B. al-Suyuthi, Al-Asybah wa al-Nazhair. Beirut: Dar al-Kutub al-Ilmiyah, 1990. 